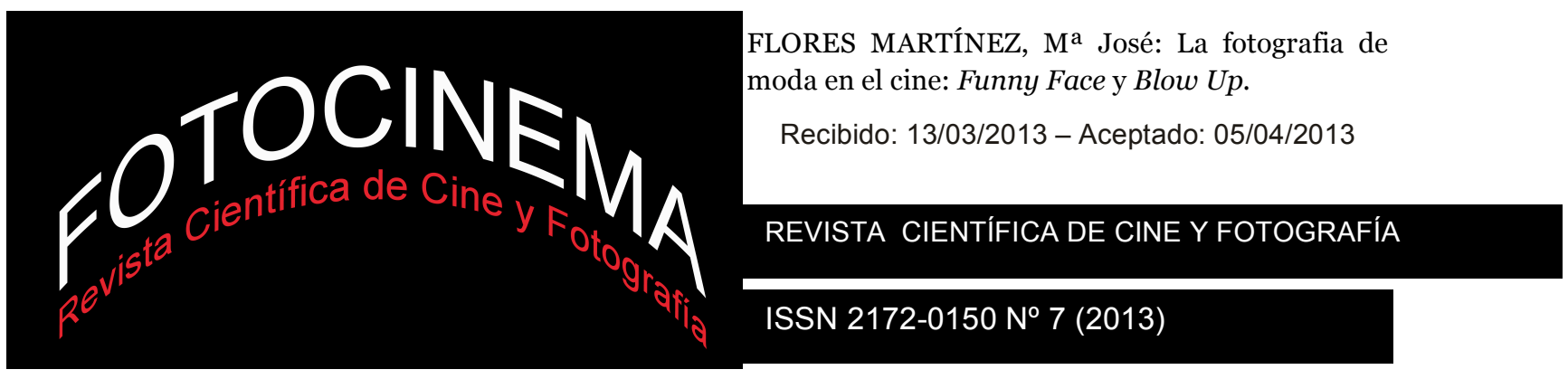

\title{
LA FOTOGRAFÍA DE MODA EN EL CINE: FUNNY FACE Y BLOW UP FASHION PHOTOGRAPHY IN FILMS: FUNNY FACE AND BLOW UP
}

\author{
Ma José Flores Martínez \\ Universidad de Córdoba
}

\section{Resumen:}

El cine, la televisión y la fotografía de moda -unida esta última a dos fenómenos económicos y sociales característicos del siglo XX: la moda y la publicidad- contribuyeron decisivamente al creciente proceso de democratización y globalización de la incipiente sociedad de masas que culminó en una nueva concepción de la cultura, la cultura popular. La fotografía de moda y el cine fueron medios de difusión de los modos de vida $\mathrm{y}$ tendencias sociales de su tiempo. Esta reproductibilidad fotográfica $y$ cinematográfica influyó notablemente en una nueva forma de entender las obras de arte y, lo más importante, modificó también nuestra forma de percibir imágenes. En este artículo analizamos el lenguaje de las imágenes de fotografía de moda que exponen dos películas que consideramos representativas: Funny Face, de Stanley Donen y Blow Up, de Michelangelo Antonioni, realizadas en las décadas de los cincuenta y sesenta del pasado siglo respectivamente..

\begin{abstract}
:
Film, television and fashion photography -joined the later to the two distinctive economic and social phenomena of the twentieth century: fashion and advertising- contributed decisively to the growing process of democratization and globalization of the emerging mass society which culminated in a new conception of culture: popular culture. Fashion photography and film media were lifestyles and social trends of this time. This photographic and film reproducibility greatly influenced a new way of understanding art and, most importantly, also changed the way we perceive images. In this paper, we analyze the language of fashion photography images displayed in two films: Funny Face, by Stanley Donen and Blow Up, by Michelangelo Antonioni; made in the decades of the fifties and sixties of last century respectively..
\end{abstract}

\section{Palabras clave:}

Cine; Fotografía de moda; Funny Face; Blow Up; Cultura Pop.

\section{Keywords:}

Film; Fashion photography; Funny Face; Blow Up; Pop culture. 


\section{Introducción}

Las décadas de los '50 y '60 se traducen en dos momentos destacados dentro de la historia del cine y de la historia de la fotografía de moda. Desde esta perspectiva analizamos dos maneras distintas de concebir la imagen y el acto fotográfico en el cine. Esto permitirá identificar señas de identidad de la nueva cultura occidental, la cultura pop, que empezó a fraguarse en estas décadas y comprobar cómo la disciplina cinematográfica y fotográfica dialogan en estos filmes.

Estas dos películas, en primer lugar, son representativas de sus respectivas épocas en cuanto al objeto de análisis que proponemos. No obstante, las visiones que se dan de este mismo tema - la primera enmarcada en la narrativa clásica hollywoodiense y la segunda, dentro de una personalísima postura de ruptura estilística que Antonioni aplicó a toda su obra- son bien distintas. Esta diversidad de planteamientos ayudará a entender la propia concepción que se tenía de la sociedad occidental cuando estas películas se rodaron. Segundo, aún tratándose de películas pertenecientes a géneros cinematográficos y concepción diferentes pueden estar relacionadas, porque, en ambas, el argumento es muy similar: su protagonista es un famoso fotógrafo de moda y, a lo largo del desarrollo de la narración, aparecen las distintas fases de su trabajo como el revelado o ampliación fotográficos, las sesiones con las modelos, su relación con las agencias de publicidad y revistas especializadas...Por último, ambas son prácticamente consecutivas en el tiempo en cuanto a la aplicación al cine de este tipo de fotografía lo que posibilita comprobar la evolución cronológica de técnicas y modos de realización durante estos periodos y valorar cómo los avances en esta disciplina van parejos a los cambios sociales o cómo esta interrelación se conecta, a su vez, con el cambio de pensamiento posmoderno propio de la crisis surgida sobre el concepto de arte durante estas décadas.

Por tanto, estos dos filmes podemos entenderlos como documentos históricos de primera fila, fuentes directas del estudio de la historia 
contemporánea. En ellas se da testimonio de costumbres y modos sociales, cambios y permanencias de aquellos años así como de las novedades producidas - desde la aparición de figuras mediáticas, los propios fotógrafos de moda y las modelos, hasta la influencia de esta disciplina técnica y artística en otros ámbitos creativos y culturales- cruciales en la configuración actual de nuestra sociedad. En definitiva, nos permiten conocer el tratamiento de la actividad creativa y técnica de la fotografía de moda y valorar la influencia que dichos filmes provocaron en su momento y su posible continuidad en la actualidad.

\section{Funny Face: La fotografía de moda en el cine de los cincuenta}

Funny Face se erige como ejemplo de diálogo entre la fotografía de moda y el cine en la década de los cincuenta. La película estadounidense de la Paramount, Funny Face, dirigida por Stanley Donen, es un musical estrenado en 1957 en Vistavision Technicolor, con canciones de George e Ira Gershwin. La película debe su título a una revista musical de los años veinte, bailada por Fred y Adele Astaire. En este momento la Paramount busca hacer la competencia a la MGM, gracias sobre todo al excelente procedimiento de la Vistavision. La historia de la película se basó en el musical no estrenado llamado Wedding Day, escrito por Ira Gershwin, que se inspiraba en un episodio de la vida del célebre fotógrafo de moda estadounidense Richard Avedon. Este artista comenzó su carrera en los años cincuenta trabajando para las revistas de moda más influyentes como Vogue, Life, Look y The New Yorker. En Harper's Bazzar se convirtió en jefe de fotografía y durante los años sesenta y setenta se consagró elevando la fotografía de moda a la categoría artística. Avedon, no sólo será el inspirador del protagonista de este filme sino que también será el consejero y diseñador de los títulos de crédito y asesor artístico. Gracias a esta colaboración entre Avedon y Donen Funny Face fue galardonada con la Mención especial del National Board of Review en 1957 por la aplicación de innovaciones fotográficas al cine. 
Avedon fue el personaje ideal de un fotógrafo de modas, el fotógrafo completo. El argumento de Funny Face se basa en la relación que Avedon mantuvo con su primera mujer Doe. El guionista de la película, Gershe, amigo de los Avedon, los admiraba y escribió el guión de una futura comedia musical vendiéndolo muchos años después al productor Roger Edens, quien lo entregó a Donen.

El número de apertura del filme "Think Pink!" o las sesiones fotográficas en distintas locaciones parisinas fueron creados siguiendo las indicaciones del fotógrafo e imitando su forma de trabajar. Además el propio Avedon asesoró a Fred Astaire (actor protagonista masculino) para que Dick Avery (personaje de ficción) saliera lo más parecido posible a él mismo.

Por otro lado, la nueva colaboración en esta película de Hubert de Givenchy y Hepburn proporcionó, como en otras ocasiones, resultados espectaculares tanto a la industria de la moda como al cine (Benavent, 2012). Estos artistas comenzaron a trabajar juntos en la película Sabrina (1954) y su relación continuó durante cuarenta años. Pero hay tres películas que marcaron el estilo Audrey y que contaron con el asesoramiento de Givenchy: Cómo robar un millón de dólares (1966), Charada (1963), filme también de Donen y Desayuno con diamantes (1961). Tanto el vestido negro con collar de perlas y moño alto de la secuencia inicial de esta última película- look que crearía estilo hasta hoy e inauguraría la comedia sofisticada de la década de los sesenta- como el abrigo rojo lucido en Charada, marcarían tendencia para siempre. Pero lo que realmente tuvo repercusión es que este estilo no se quedó sólo en la pantalla ya que Audrey mantuvo su peculiar imagen en todas sus apariciones públicas. A mediados de los 50, cuando realizó esta película, Audrey ya era una de las mayores estrellas de Hollywood y considerada icono indiscutible de la moda. Esta actriz impuso la tendencia del look causal, en lugar del glamor habitual. Fue la pionera de las "muchachas no divas", que son toda una pauta de nuestra época. Su innovación, su prefiguración de la espontaneidad juvenil y su frescura impusieron un estilo que aún sigue vigente (Tejero, 2010). 


\subsection{La concepción de la imagen de Stanley Donen en Funny Face}

La concepción de la imagen de su director, Stanley Donen, debe ser interpretada desde su producción cinematográfica: de las 23 películas que realizó 13 de ellas fueron musicales (5 codirigidas), 9 comedias y una dramática. Por tanto, su obra aparece englobada en dos géneros definidos, pudiendo encuadrar su cine dentro de la comedia americana de los años 1934-1963, con películas memorables como Un día en Nueva York o Cantando bajo la lluvia, en las cuales tratará el tema de las apariencias como hace en Funny Face. Su estilo visual está muy cercano al estándar de la comedia clásica americana aunque considerablemente flexible. Donen ve la vida como una comedia en la cual se estiliza la realidad, pero esta estilización no impide que llegue hasta el fondo de las relaciones humanas, convirtiéndose, para muchos, en uno de los más finos y penetrantes autores de comedias del cine contemporáneo. Él caracteriza las relaciones como flujos o corrientes entre las personas. Por ello, puede decirse que el cine de Donen es un cine más de relaciones que de personajes. Esto otorga una dimensión física a su cine que se muestra en los dos temas esenciales de su obra: la variabilidad de las relaciones interpersonales y los efectos negativos del paso del tiempo.

Donen hace un cine "fácil" de ver por la claridad de sus imágenes y de la narración. En sus películas introduce la distancia de los planos generales, los planos americanos o el plano medio como forma de visualizar mejor todos los movimientos de los actores y las circunstancias donde se desarrolla la acción. Podríamos decir que Donen se limita a contemplar, eso sí, con atención, para que podamos descubrir, junto a él, lo que subyace bajo las apariencias. De esta forma, como consecuencia de esta concepción, los planos en sus películas pasan de detenerse en miradas o gestos, dilatando así la escena, a otros planos breves en los que se captura la mirada o el gesto tal vez contradicho por las palabras o disimulado. El cine de Donen se convierte de esta manera también en un arte del instante. 
Esta actitud de Donen que comentamos se refleja en el juego de dicotomía que aplica en Funny Face. Contrapone lo superficial y frívolo de Avery a lo profundo y grave de Jo. Y para ello, Donen usa el color. Este elemento se convierte en decisivo para el desarrollo del argumento ya que mediante él se ilustra expresivamente la oposición entre los personajes, sus mundos profesionales, sus aspiraciones e intereses. Estas posiciones antagónicas de los protagonistas, que acaban enamorándose, manifestadas mediante los colores de su ropa, también nos hacen intuir sus emociones y contradicciones y muestran gráficamente la posterior transformación del personaje femenino cual metáfora de la transformación de una larva en mariposa, símbolo, para muchos, de la transformación total.

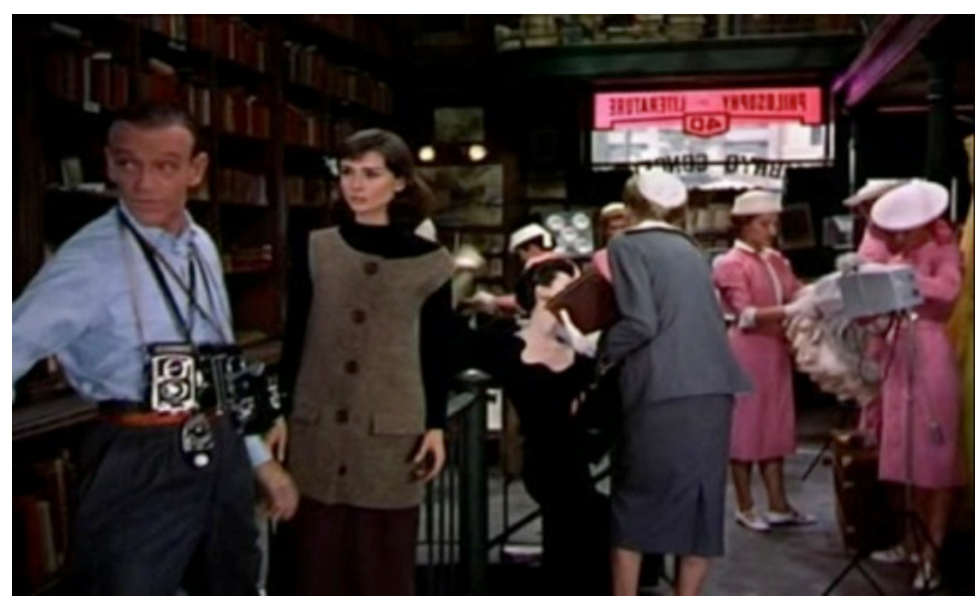

F1. Funny Face de Stanley Donen (1957)

El género musical le sirve también para caricaturizar las ideologías imperantes de la época. En Funny Face nada es, aparentemente, serio. Es posible, que esta película, a parte de su calidad cinematográfica, aporte una lección: el punto medio. El punto de vista de Donen capta la esencia de las diversas formas de vida posibles de la época: “[...] mediante una interpretación sociológica de lo que los naturalistas creen que es la realidadcuando no es más que la apariencia-, sino a través de la penetración con que examina las relaciones que se establecen entre diferentes personas y en diferentes ambientes" (Marías, 1972). En Funny Face el discurso hecho sobre la teoría filosófica del "enfaticalismo", defendida por Jo, adelanta corrientes que vendrán ya en la década de los sesenta y se afianzarán tras el Mayo del 
68. La empatía, la comprensión del otro, de su situación y el respeto, son, en esta película, como el camino del encuentro entre los seres humanos. Colo Tavernier en su crítica de Staircase [dice]: «Dan ha querido que los apreciemos como son...Dan ama a sus personajes, sin despreciarlos...Lo que es genial de Dan es que haya sabido amar tanto, viendo tan claro...» (Marías, 1972). Así, Donen hace una amable caricatura de Sartre en la piel de Michel Auclair como un profesor Flostre farsante, tan manipulador y mundano como pudiera ser un profesional de la moda, al que Avery le replica: "Flostre se preocupa por vuestra inteligencia tanto como yo". Con esta frase queda claro que la frívola moda se inviste de dignidad frente al docto intelectualismo, se reconoce a sí misma como posible manipuladora pero en el sentido positivo del término, manipula la realidad para crear un mundo más hermoso. Desde el punto de vista ético queda claro que un tema como la moda puede hacer reflexionar sobre la sociedad y nunca antes, refiriéndonos a la desarrollada durante el siglo XX, generó tan fértil debate.

\subsection{El acto fotográfico en Funny Face}

En esta película Donen traslada a la gran pantalla el método de trabajo de Avedon. Esto podemos comprobarlo, por ejemplo, en la escenificación de las sesiones en las que Dick Avery fotografía a Jo en lugares emblemáticos de París. Desde el punto de vista técnico, en estas escenas, las imágenes fijas se retocan y desfiguran: junto a los negativos y diversas separaciones de color, se ven positivos en blanco y negro parcialmente coloreados y modificados. Desde el punto de vista artístico, se refleja fielmente el trabajo que el fotógrafo hacía en sus sesiones en exteriores. En ellas introducía la narrativa y la emoción haciendo que las modelos posaran de forma natural y expresiva.
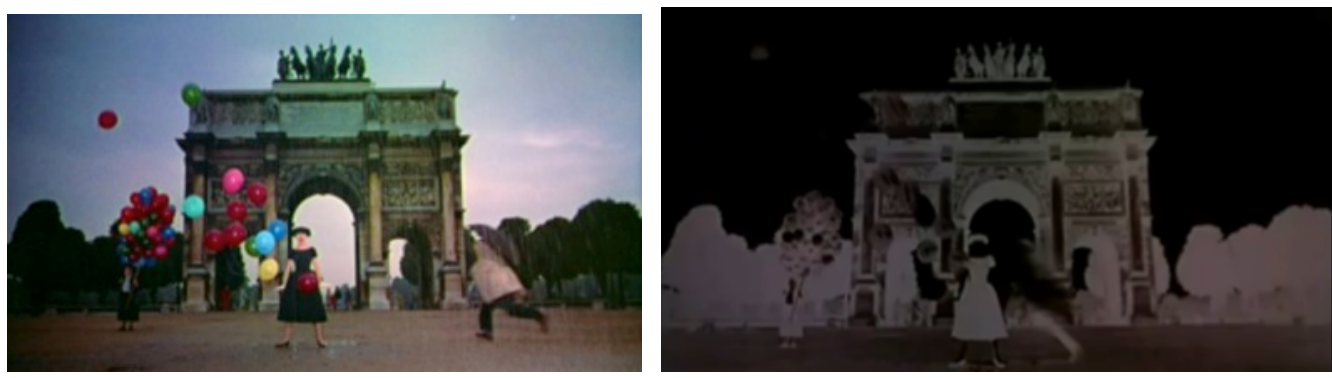

79 

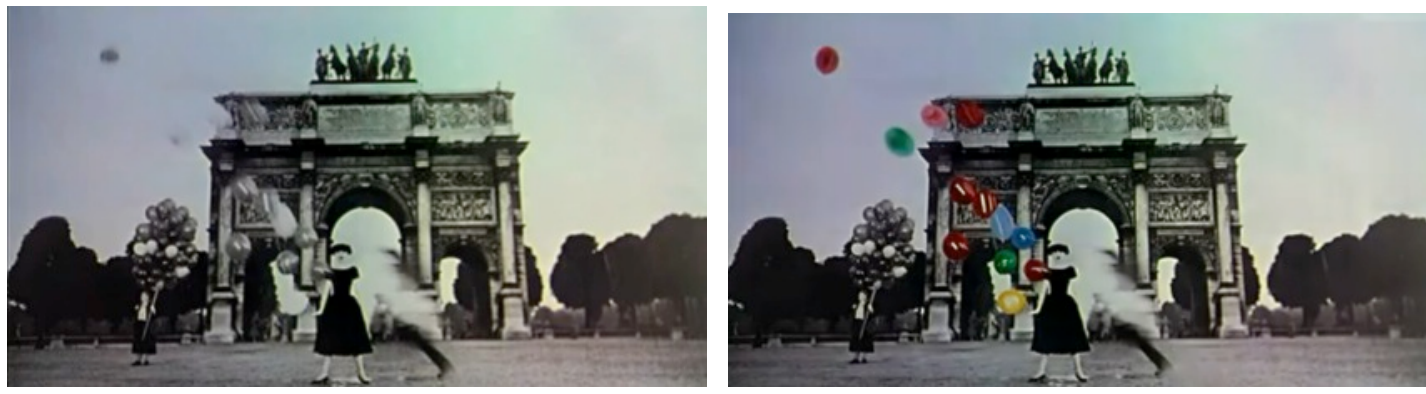

Fotogramas que ilustran fielmente el método de trabajo de Avedon: F2 "Congelación" imagen, F3 Negativo, F4 Positivo en blanco y negro, F5 Positivo en blanco y negro, coloreado y modificado con recortes.

Otra técnica fotográfica de Avedon que Donen adopta en este filme es la basada en la aplicación de filtros de color a imágenes fijas, “congeladas”, como vemos en el caso siguiente:
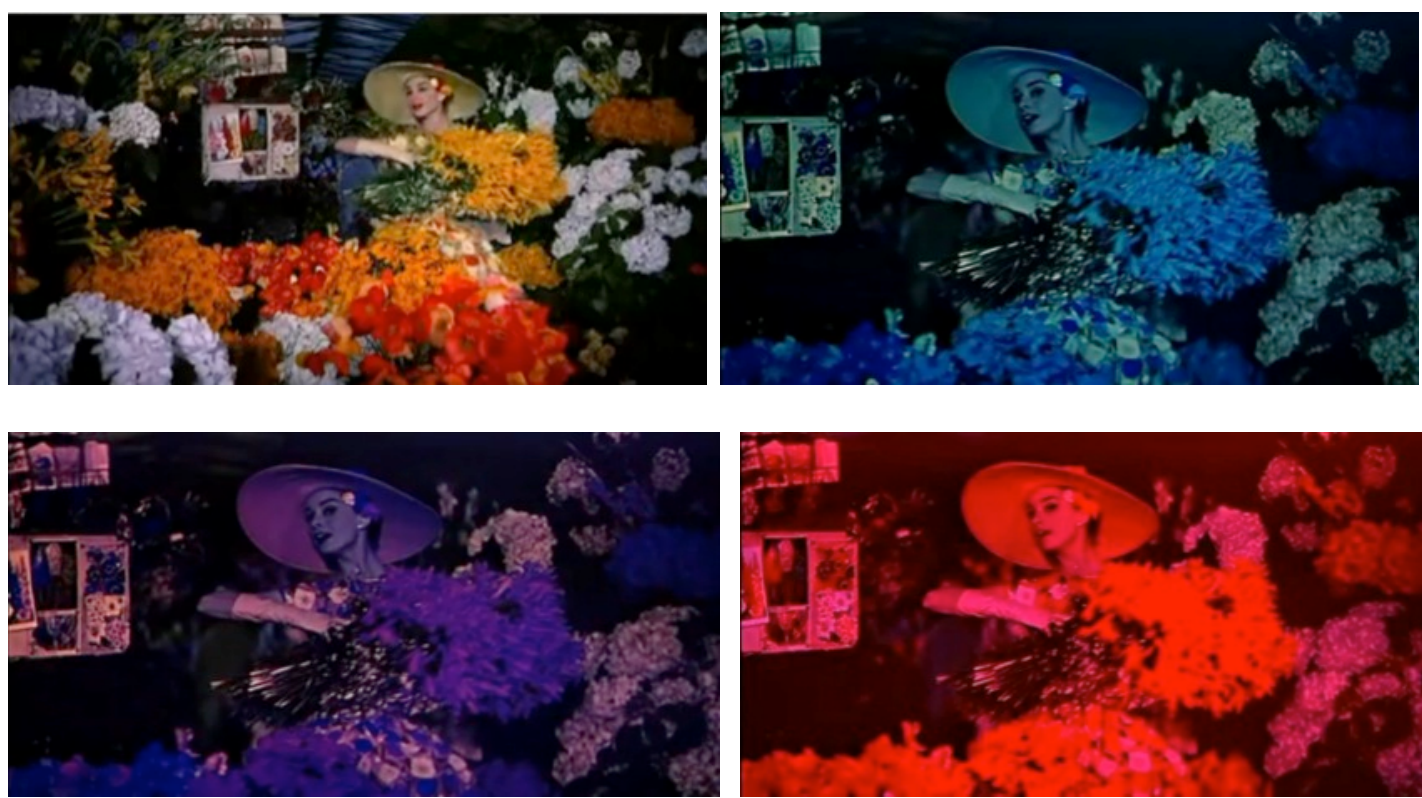

F6, F7, F8 y F9. Fotogramas de la sesión fotográfica de Avery y Jo en el mercado de flores.

F6. Imagen fotograma "congelada". F7. Filtro azul cyan. F8. Filtro azul violeta. F9. Filtro rojo magenta.

La imitación de la técnica de la sobreexposición fotográfica (dodging) fue una de las innovaciones que distinguió a esta película con el premio del National Board of Review. Esta técnica fotográfica consiste en la excesiva exposición a la luz de un material fotográfico, así los negativos sobreexpuestos (en color o en blanco y negro) suelen carecer de contraste y 
del detalle de las luces, dándose diapositivas muy transparentes y con luces quemadas.

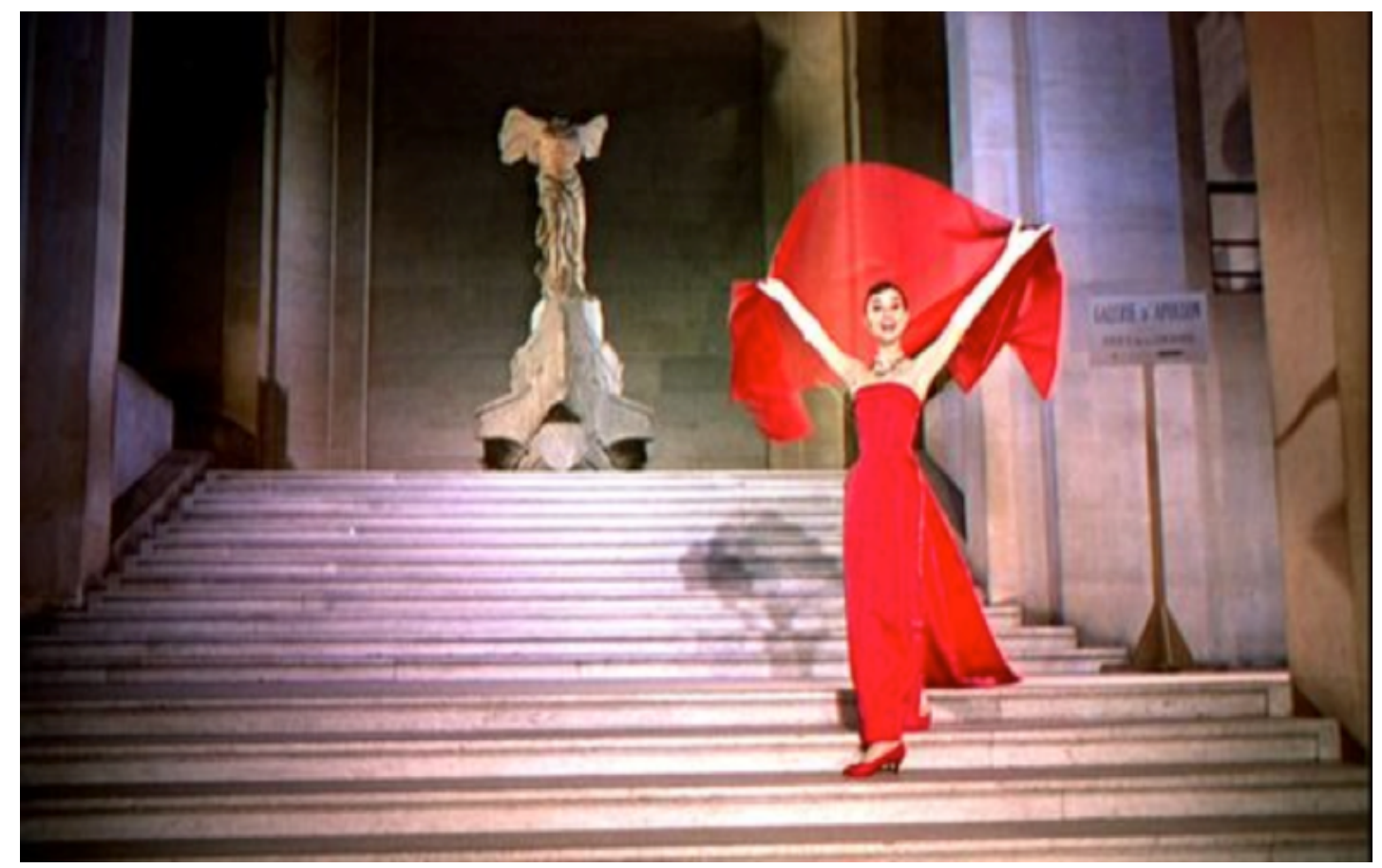

F10. En este fotograma Donen recrea la sobreexposición fotográfica o dodging.

Por último, el objetivo de flou es un objetivo fotográfico especial que se utiliza para trabajos muy concretos ya que tiene un nivel de aberración esférica que produce un alto grado de difusión o efecto de halo (en la última escena la fotografía de Ray June se deleita sobre todo en los efectos de la bruma irisada). Al final de la película, en la escena de cierre, vemos que Jo lleva un vestido blanco de novia (vestido que suele significar el cierre tradicional de una colección de moda) y Dick Avery un chubasquero blanco. En esta escena de cierre, alrededor de los protagonistas, vemos cisnes y palomas también de color blanco. Los colores simplemente se disuelven en una luz difusa, un efecto que aún se refuerza más mediante la sobreexposición y el citado objetivo de flou. 


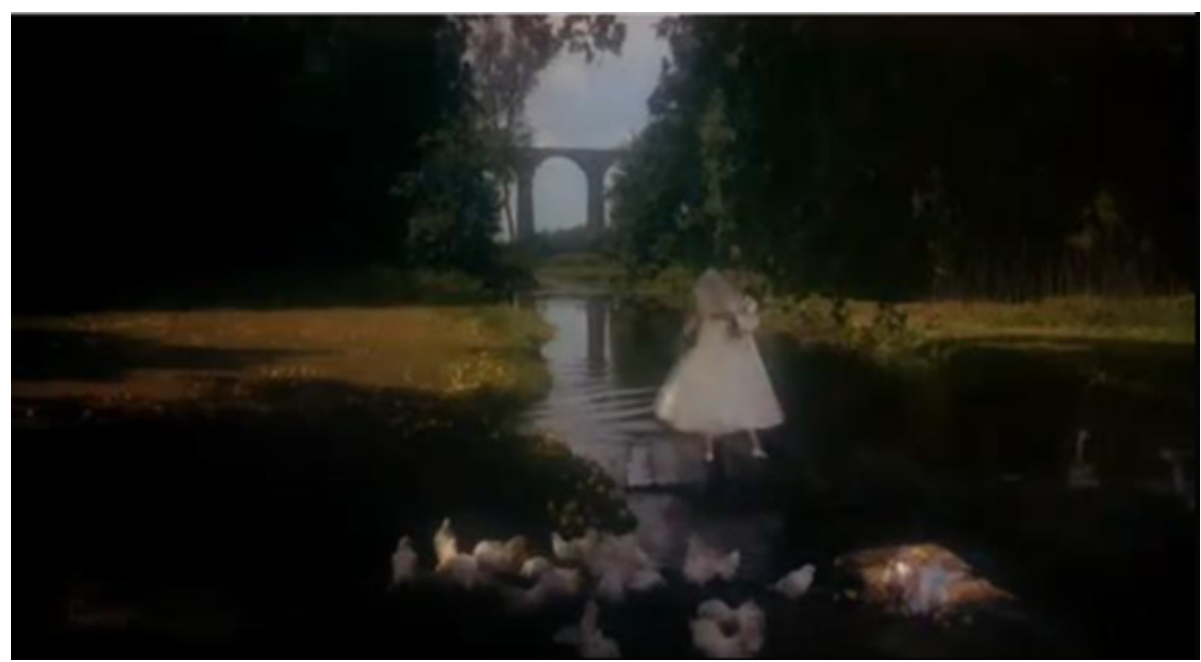

F11. Recreación de sobreexposición y efecto flou fotográficos.

Todos estos métodos fotográficos que hemos expuesto aparecen, de manera condensada, en los títulos de crédito diseñados íntegramente por Avedon. El primer número musical titulado "Piensa en rosa", que trata del nuevo diseño de temporada, de la nueva tendencia que la revista de moda Quality quiere lanzar, imita nuevamente el estilo de Richard Avedon. En estas fotografías/fotogramas las modelos se muestran libres y dinámicas -no indiferentes o sumisas como era costumbre en la época- dentro de unos marcos escénicos previamente decididos (F12).
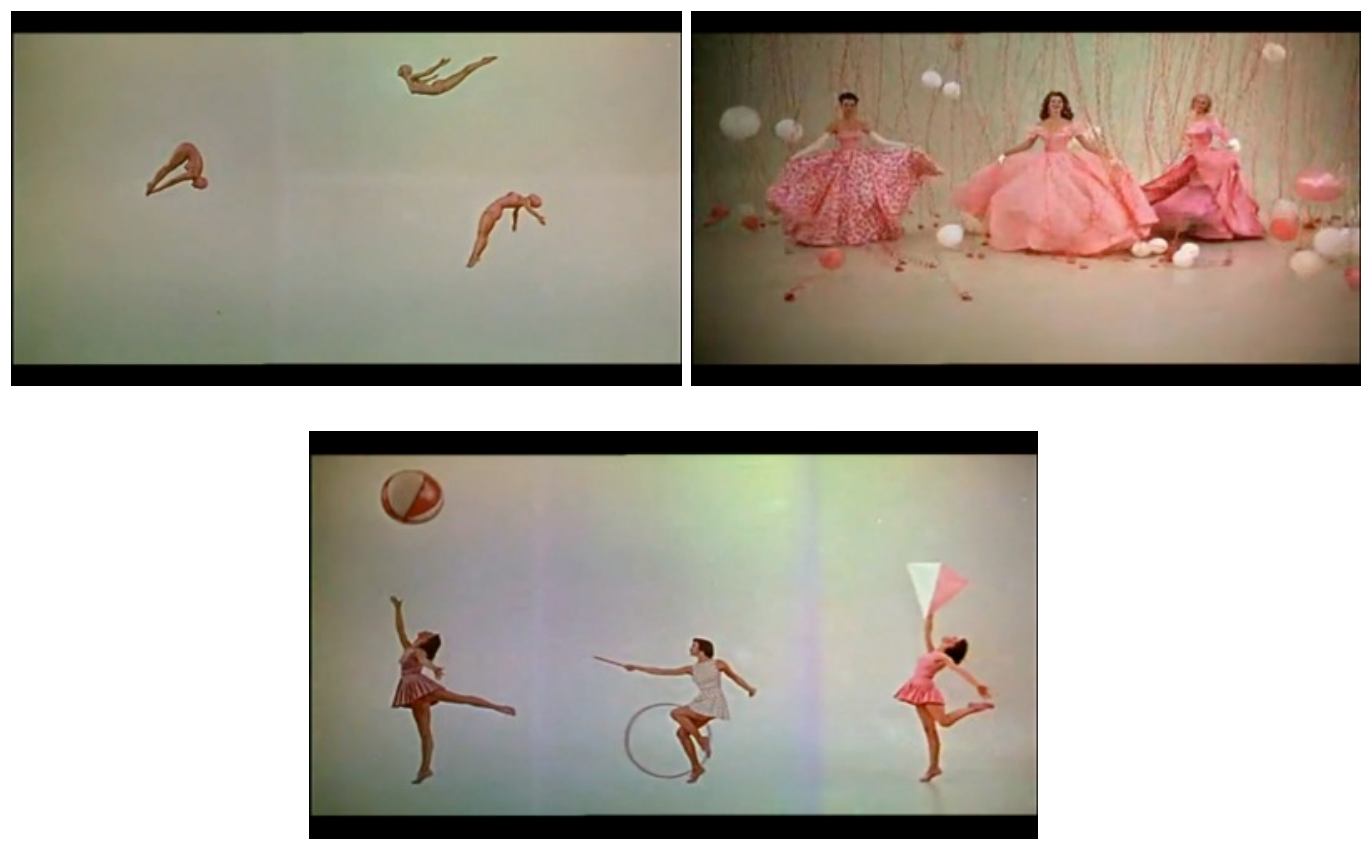

F12. Fotogramas del número musical "Piensa en rosa".

82 
No sólo la aplicación de estos procedimientos fotográficos o la intensa presencia de Avedon y la participación de Audrey Hepburn convierten a Funny Face en una película determinante para entender el diálogo de la fotografía de moda y el cine sino que hay otros elementos que conectan esta película con la industria de la moda y tendencias de su tiempo tales como los desfiles de Alta Costura de Christian Dior en todo su apogeo, el ambiente del París como capital de la moda y la aparición de las primeras modelos famosas, precedentes de las futuras Top Models, como es el caso de Dovima (F13) - musa de Avedon- y Suzy Parker (F14).

Por todo ello, podemos considerar que esta película se trata de un documento muy significativo para leer la moda del siglo XX aunque en su época no fue comprendida así.
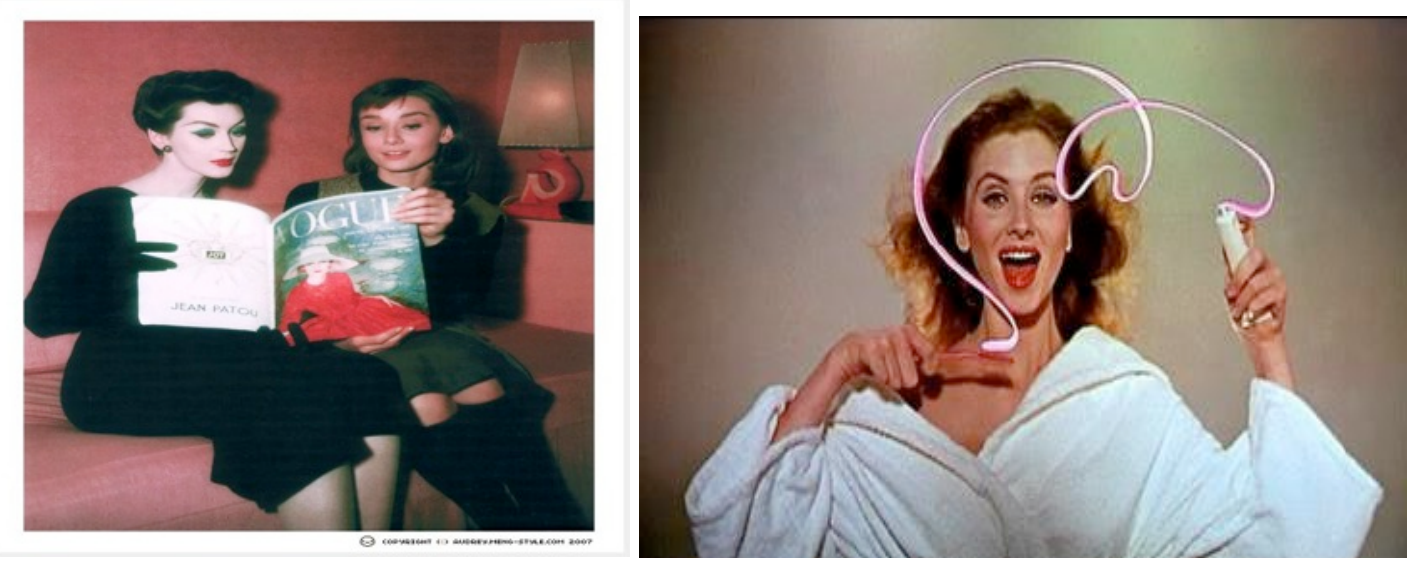

F13. Audrey y Dovima en un descanso del rodaje de Funny Face y F14. Fotograma con la imagen de Suzy Parker.

\section{Blow Up: La fotografía de moda en el cine de los sesenta.}

En 1966, Antonioni dirigió Blow Up. Esta película fue su mayor éxito con el público. La historia está situada en Londres durante los Swinging Sixties, centrada en un personaje masculino utiliza un estilo de ritmo más rápido que en otras producciones anteriores suyas, aunque mantiene en ella el tema de la alienación y explora la realidad a través de las apariencias, como lo hace Donen en su película. Los antecedentes de este proyecto los encontramos en uno de los tres episodios de su película I vinti (1953) rodado en Londres 
donde aparecen muchas localizaciones que volverán a salir en Blow Up y en su corto I tre volti (1965) el cual le sirvió como precalentamiento antes de rodarla y del que se extrajo un documental, Storia di un autore (1966), donde se muestra la manera de rodar de Antonioni. Blow Up fue nominada a dos Premios de la Academia: Mejor Dirección y Mejor Guión Original (Antonioni, Tonino Guerra, Edward Bond), además de ganar la Palma de Oro en Cannes y el Premio de la Sociedad Nacional de Críticos de Cine a Mejor Película.

El título en inglés Blow Up significa la explosión de una burbuja, aunque se entiende en la jerga fotográfica como una gran ampliación durante el revelado de una fotografía. La historia está basada en el relato de Julio Cortázar Las babas del diablo -como homenaje a Cortázar, el director italiano incluye la imagen del escritor en una de las fotografías mostradas en la película a modo de cameo-. Ambos relatos son completamente distintos, aunque el personaje central de los dos textos es un fotógrafo (profesional en la película, aficionado en el cuento) cuya cámara capta, al azar, una escena perturbadora en un parque. El misterio de esa escena lleva a los protagonistas, tanto del cuento como de la película, a cuestionarse por el significado de la realidad fotografiada. Ambos se obsesionarán con la imagen "revelada” llevándolos a ampliar sucesivamente la imagen enigmática que no son capaces de entender.

Esta película además de una obra de arte cinematográfica, es también considerada una gran obra de filosofía. Aspecto este presente también en Funny Face, como dijimos, pero tratado por Donen extrínsecamente. Es decir, más como reflexión de lo social, del pensamiento imperante ("enfaticalismo") y no como una reflexión psicológica, de lo individual, como es el caso de Antonioni en Blow Up. Así, es preciso señalar, que su influencia estética y ética se dio en casos como el de la nueva generación de cineastas de Hollywood de finales de los sesenta y principio de los setenta. Francis Ford Coppola en su película La conversación (1974) o Brian De Palma en Blow Out (1981) buscaron una renovación de la industria y la creatividad cinematográfica norteamericana. En este aspecto señala Biskind: "Era la 
Edad de Oro del cine europeo y japonés de posguerra, los días de la Nouvelle Vague francesa, de Ingmar Bergman, de Akira Kurosava, de Michelangelo Antonioni y Federico Fellini. Aunque sus películas fueran "foráneas", parecían más inmediatas, más americanas que cualquier cosa que Hollywood produjese. Daban en el blanco: el público se reconocía en ellas" [...] No habían mapas en esa jungla de cambios. Nadie había abierto una senda”. (Biskind, 2004: 22).

La importancia y vigencia de esta película no sólo le viene por su calidad, que muchos han discutido, sino por otras tantas virtudes. La película se desarrolla en "tiempo real", en presente, en el momento del transcurso de los acontecimientos que revolucionaron la sociedad de los sesenta y en el lugar donde se fraguaban, Londres. Aquí, otra vez, como en el caso de Funny Face, la ciudad se convierte en otra protagonista. Y, también, como pasa en la película de Donen, encontramos la presencia implícita de una figura destacada e influyente del momento, David Bailey, fotógrafo que inspira el personaje protagonista y otras figuras relacionadas con el mundo de la moda y la cultura, explícitas -muchas se interpretan a sí mismas- como las modelos Verushka, Peggy Moffit o una jovencísima y, hasta ese momento desconocida, Jane Birkin y el grupo de música The Yardbirds interpretando el tema Stroll On.

F15. Las modelos Verushka, Peggy Moffit y Jane Birkin en Blow Up.

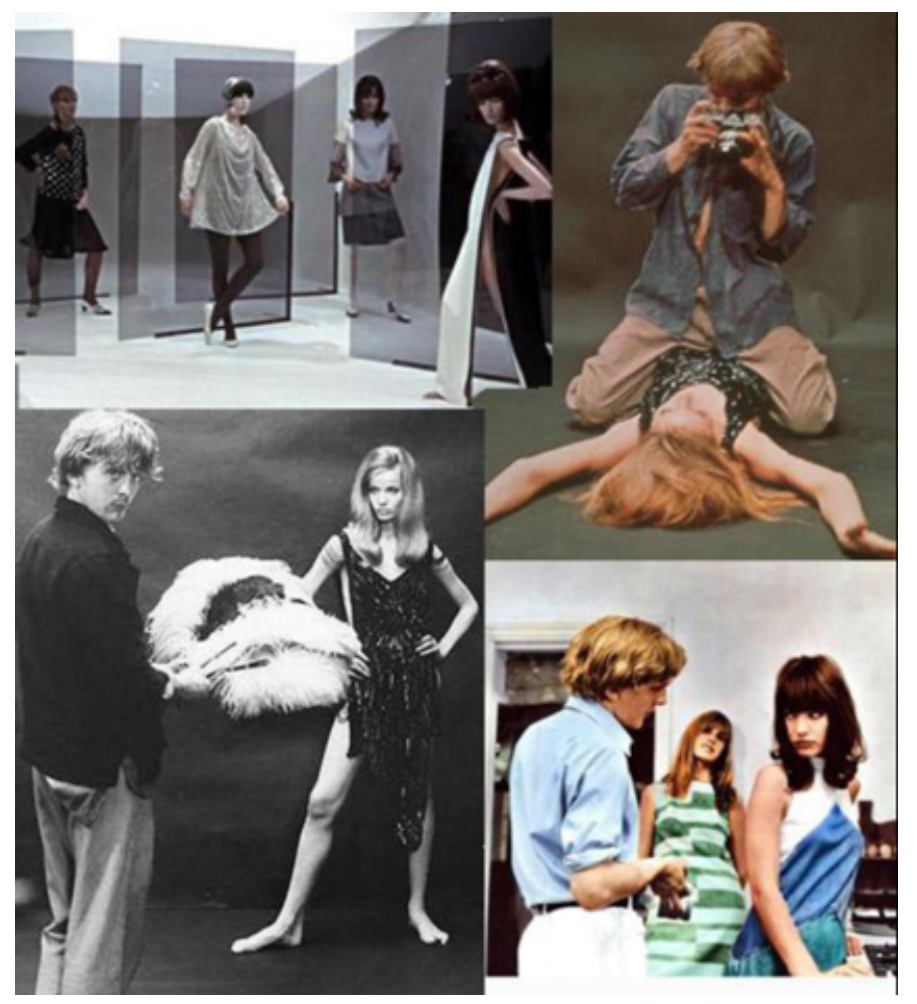




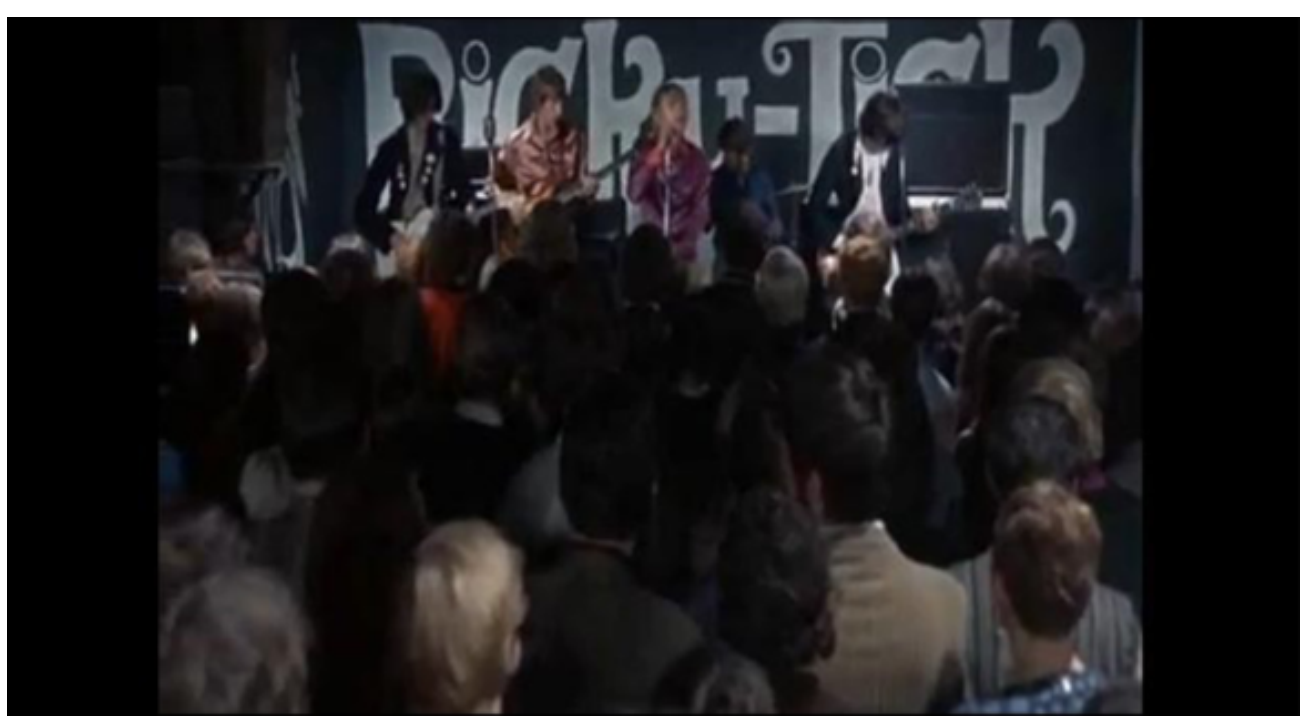

F16. Imagen de la derecha, fotograma con The Yardbirds interpretando el tema Stroll On en BlowUp.

$\mathrm{Y}$, con respecto a las influencias en la propia forma de vestir que esta película produjo, destacar, como ejemplo, que a partir de su estreno se impuso la moda de los vaqueros blancos con chaqueta y sin corbata, atuendo que luce el actor David Hemmings a lo largo de toda esta película (F17).

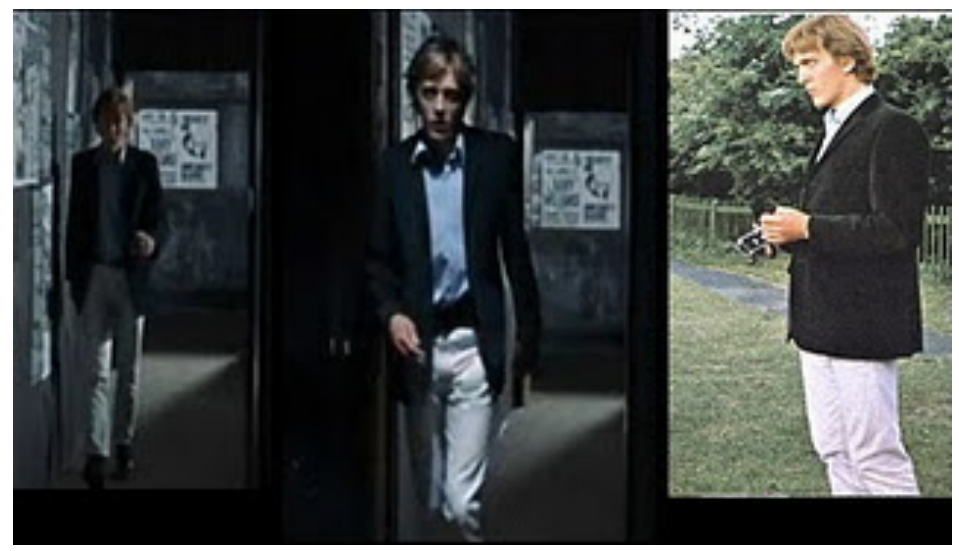

F17. Fuente:

[http://comovestimos-

lo.blogspot.com.es/2010_10

_01_archive.html]

26/02/2013.

En cuanto al aspecto que a nosotros nos concierne el filme es un despliegue de momentos en los que el desarrollo de la profesión del fotógrafo de modas aparece: sesiones con las modelos, preparación de esas sesiones en el estudio del fotógrafo, ayudantes, presencia de aspirantes a modelos, escenas en las que aparecen procedimientos técnicos del tratamiento de las instantáneas, el resultado de esas fotografías, las relaciones del fotógrafo con personajes afines al mundo de la moda. 


\subsection{La concepción de la imagen de Michelangelo Antonioni en Blow Up}

Sobre Antonioni hay una extensísima bibliografía que aborda en profundidad su cine. Para este caso que nos ocupa podemos hacer referencia a trabajos como el de Aurora Conde Muñoz que en su artículo "La precisión de la nada (reflexiones sobre Blow Up)" (Conde, 2008, p. 157-179) hace una valoración general de la producción cinematográfica de Antonioni hasta la realización de Blow Up, para posteriormente analizar el contenido metatextual de esta película en referencia al cuento de Cortázar; o el estudio de Isabel Paredes que define la forma de representación del director italiano de la siguiente manera: "El cine de Antonioni es un cine físico, muy físico. Sus imágenes recogen los paisajes en toda su materialidad, en ocasiones, obviando lo que esconden y dejando que representen exactamente lo que son, relacionando esa fisicidad con la de los personajes y con sus problemas creando un conjunto muy material" (Paredes, 2006, p. 31). Este materialismo parte de las convicciones ideológicas de su autor. Antonioni se define como marxista: "[...] or else resorting to the aoutdated clichés of the post-religious Marxist existentialist of modern alienation and ennui, [...]” (William, 2008, p. 46), pero también es un hombre de su tiempo en contacto directo con las últimas tendencias artísticas -en esta película "vemos a través de los ojos de otro, un intermediario que es la vez artista y público" (Losilla, 2005, p. 69)-. La fisicidad de su trabajo y su interés por las nuevas tendencias socioculturales de su tiempo lo conectan con Stanley Donen. Ambos directores desean entender qué está pasando a su alrededor, la realidad de su tiempo.

Por su parte, el propio Antonioni dice sobre su concepción de la imagen en esta película: "Mi problema en Blow Up era el de recrear la realidad de una forma abstracta. Yo quería discutir "la realidad presente": éste es un punto esencial del aspecto visual de la película, dado que uno de los temas principales de la película es ver o no ver el valor exacto de las cosas” (Antonioni, 2002, p. 133). Gideon Bachmann recoge otras palabras de Antonioni al respecto "What counts is the reality that ends up on the screen. 
My reality" (Bachmann, 1975, p. 28). Blow Up puede interpretarse, por tanto, como una reflexión sobre el sentido y valor de la imagen, de lo visual y del cine en el mundo contemporáneo. Esta concepción de la imagen identificada con la propia concepción de la realidad, aquella que Antonioni quiere representar queda ilustrada, no sólo en el conjunto resultante de la película, sino que surge en momentos puntuales, en determinadas escenas que dan la clave sobre lo que Antonioni quiere presentarnos y cómo quiere hacerlo. Una de esas escenas es aquella que reproduce el encuentro entre Thomas y su amigo pintor, Bill, en la casa de éste. Esta escena es significativa porque es de las pocas de la película donde la palabra adquiere tanta presencia como la imagen. En ella se advierte que Antonioni hace una comparación entre la percepción de la realidad y la percepción artística:

BILL: Es cosa de hace cinco o seis años. Cuando los hago no me dicen nada. Una chapuza. Sin embargo, después de cierto tiempo encuentro algo a que agarrarme, como aquella pierna. Y entonces sale solo. Es como encontrar la clave de una novela policíaca (Antonioni, 1968, pp. 347-348).
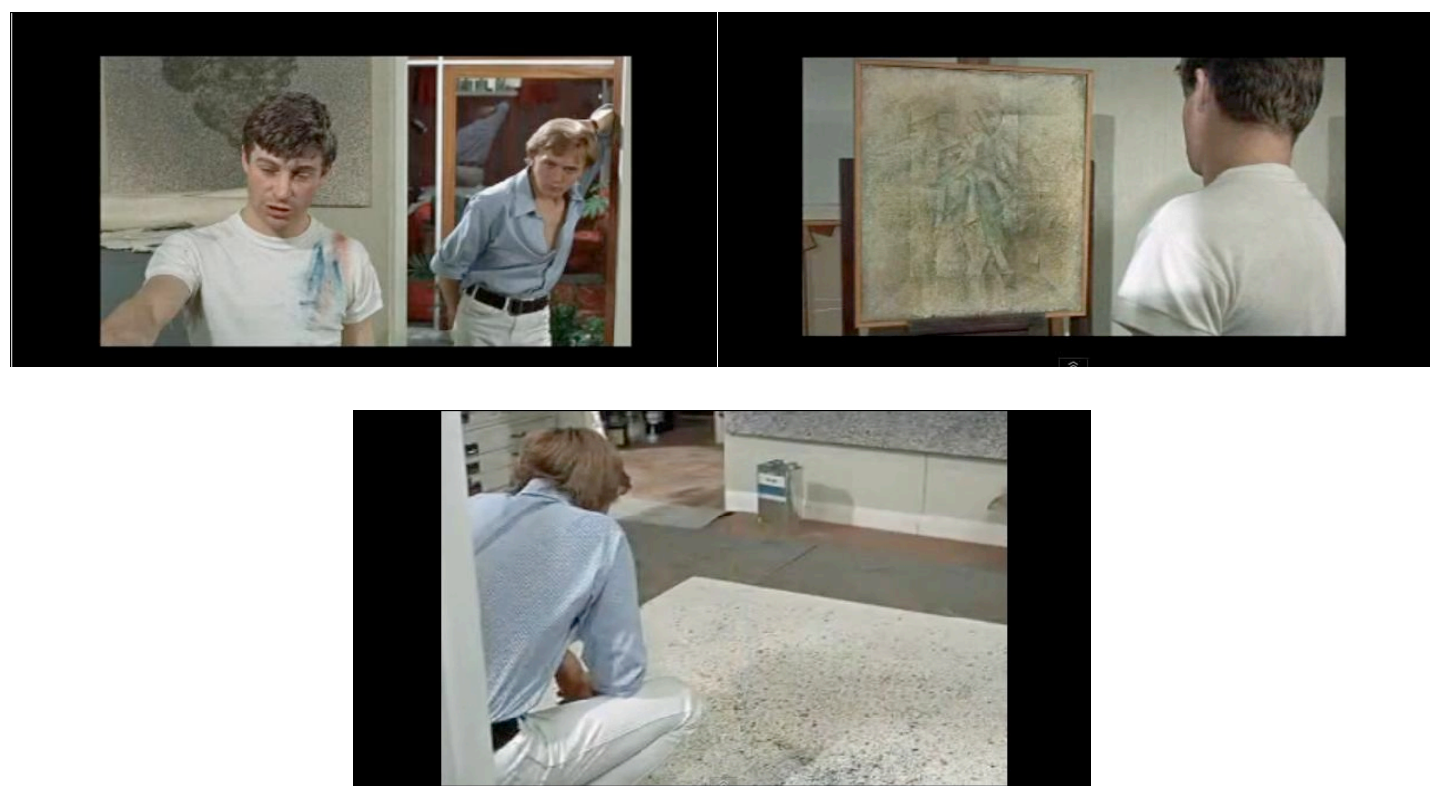

F18, 19 y 20. Fotogramas de la escena en casa de Bill.

En este pasaje se anticipa el quid de la trama. Aquí Antonioni se refiere a la importancia del detalle. La siguiente escena que explica esto que comentamos es la que tiene lugar en la casa-estudio de Thomas con Patricia. 
Ella llega a la casa del fotógrafo tras el descubrimiento de Thomas del cadáver en el parque y en un momento de la conversación dicen:

FOTÓGRAFO [protagonista]: Ahí está el cuerpo (Patricia se inclina, recoge la ampliación y la mira. Luego se vuelve de nuevo hacia el joven).

PATRICIA: Parece casi un cuadro de Bill.

FOTÓGRAFO: Sí [...] (Antonioni, 1968, p. 383).

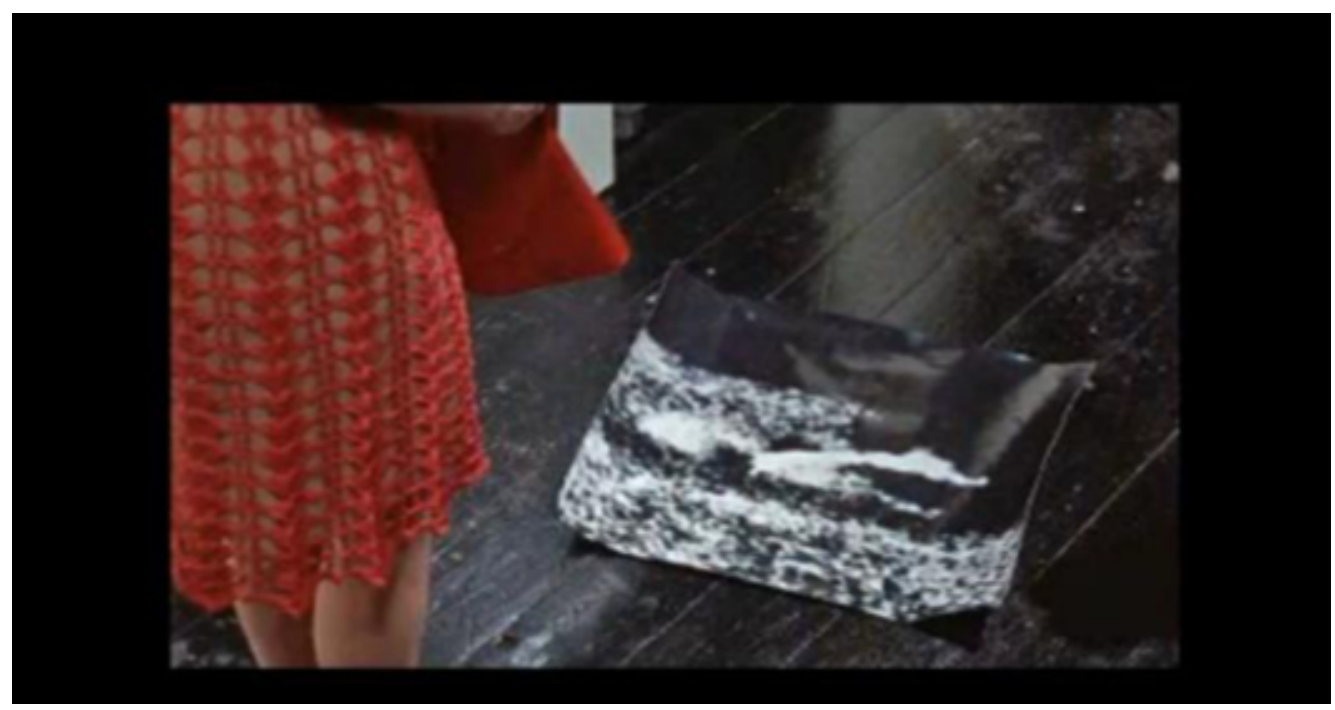

F21. Fotograma de esta escena donde Patricia recoge del suelo la ampliación.

La conversación prosigue en una compleja ambigüedad de silencios y gestos que dejan al descubierto que ambos están preocupados por razones distintas, dentro de sus realidades individuales. Aquí también, cada uno, tiene una percepción distinta de lo que pasa a su alrededor, es como si Antonioni nos quisiera hacer entender que cada uno de nosotros tenemos la incapacidad de ver la realidad total, que sólo percibimos la realidad desde nuestro punto de vista y que esto es fuente de incomunicación e incomprensión, tema constante en su obra cinematográfica.

Por último, otra escena para entender la concepción de la imagen de Antonioni es la escena de cierre. Ésta es fundamental para comprender el curso del film y su temática. El plano general en el cual aparece Thomas, el protagonista, rodeado por el parque (F22) hace que éste sea "un punto, un detalle, dentro del conjunto, lo mismo que lo era el cadáver” (Paredes, 2006, 
p. 32) que descubre a partir de las diversas ampliaciones fotográficas (F21) e igual que las "figuras" que Bill ve en sus pinturas (F19 y F20).

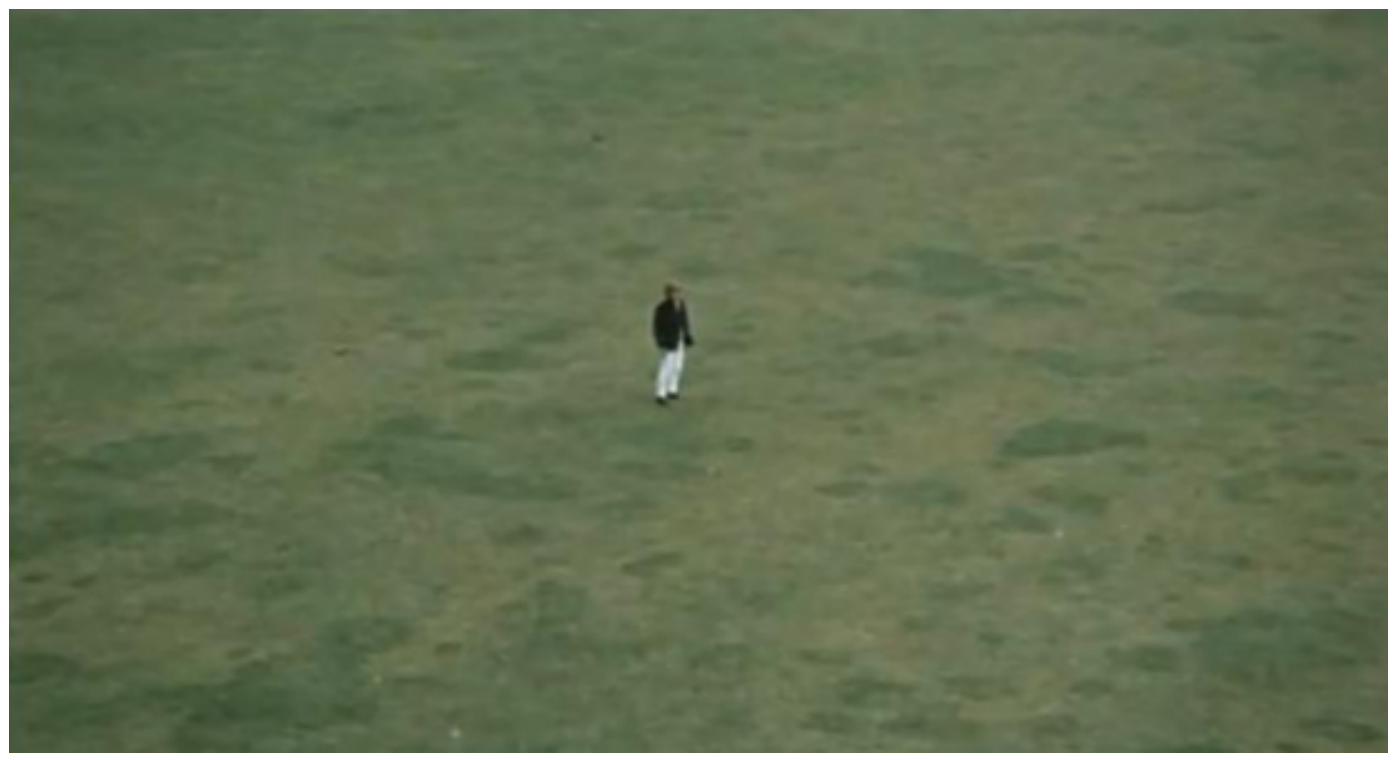

F22. Plano general final de Blow Up. Fuente: DVD de la película.

Para terminar, al hilo de lo que decíamos, se aprecian otras dos escenas que son una alusión de Antonioni al mundo del arte en general y a la pintura en particular. Ambas transcurren en una misma tienda de antigüedades londinense. Thomas, en la primera escena busca un cuadro de paisajes pero en la segunda termina por adquirir la hélice de un aeroplano. Estos pasajes, que en la película parecen no tener un significado evidente, recuerdan una anécdota atribuida a Duchamp y Brancusi durante su asistencia a una exposición aeronáutica en la cual el primero dijo: "La pintura ha muerto. ¿Quién podría hacer algo mejor que esta hélice?”.

Es fundamental analizar cómo trata Antonioni los objetos que llaman la atención de Thomas en la tienda de antigüedades -el cuadro de paisajes y la hélice- para entender esta referencia y la manera de enlazar las dos escenas. La primera vez que Thomas aparece en la tienda es atendido por un hombre gris y mayor, poco motivado, de aspecto cansado, dependiente del local. Thomas le pide que le enseñe un cuadro de paisajes pero el hombre insiste en

1 Este comentario lo hizo en 1912, fecha a partir de la cual Duchamp inicia su despedida de todo arte al uso y crea nuevos objetos estéticos como los Ready-mades, estuches e instalaciones. 
que no tiene en la tienda aunque el fotógrafo está viendo algunos en un lugar apartado de la misma. Este viejo es como la personificación del arte moderno, el cual ha quedado relegado de su posición de privilegio. Ante la actitud recelosa y esquiva del hombre que atiende a Thomas se opone la jovial y confiada de la joven propietaria que aparece en la segunda escena. Se trata de una chica con inquietudes, llena de proyectos y, en cierto sentido, promesas. Ella es la personificación de la nueva generación de los sesenta, llena de dinamismo y cambios. En esta escena también el objeto es encontrado por Thomas oculto entre otros muchos pero no se puede interpretar su hallazgo como algo incómodo- como sucede con el cuadro de paisajes- sino como todo un descubrimiento gozoso y divertido.

Esta segunda escena será la que nos haga pensar en las palabras de Duchamp. Como comentó Apollinaire en 1913, Duchamp pretendía crear "un arte que no se inspirara en la naturaleza para extraer generalizaciones intelectuales, sino formas y colores colectivos, que nuestra apreciación no ha conseguido aún descifrar [...]” (Apollinaire, 1912). También Arthur Danto en su libro Después del fin del arte reflexiona sobre los cambios en el arte tras la aparición de esta nueva forma de plantearse la obra artística: "Alrededor de 1917, con los Ready-made y luego en 1964 con la Brillo box Duchamp y Warhol demostraron que sus objetos eran arte, aunque no bellos; lo cual significaba que eran imposibles de describir en términos de estética clásica. Así, se aclaró que la belleza u otra categoría estética, no formaba parte de ningún atributo para definir el arte- Si lo bello no es una distinción entre las obras de arte y otras cosas, entonces la belleza no formaba parte del concepto de arte" (Danto, 1999, p. 106).

He aquí el paralelismo que podemos encontrar entre la forma de entender el cine de Antonioni y la nueva concepción de la obra de arte las cuales se alejan de los cánones estéticos clásicos. Este guiño del cineasta que planteamos tiene que ver con lo que señala Ana Melendo sobre la obra del director: "En la filmografía antoniniana se produce una ruptura estilística con respecto a otros modelos de representación ya desde su primer largometraje: Crónica de un amor (1950)" (Melendo, 2010, p. 90). 
Si reparamos en la fecha en la que Brillo Box tiene su aparición -dos años antes del estreno de Blow $U p-$ y visto lo expuesto hasta ahora, viene al caso citar las siguientes palabras de Aurora Conde: "En esta película se llega al cine experimental. Antonioni asimila las reflexiones teóricas que impulsaron los estudios estéticos a partir de los años 60 y que contribuyeron de forma definitiva a la revisión del valor de lo visual, especialmente en su relación con las otras artes (desde las propuestas de John Cage, pasando por las teorías de Gombrich), añadiendo precisamente el cine, y sus revolucionarias capacidades interdisciplinarias, a la nueva definición de texto semiótico. Hay que atender por ello a los estudios de Barthes, Marin, Alpers, el propio Deleuze, por citar sólo algunos nombres, para entrar correctamente en la compleja infraestructura teórica del filme que desplaza la centralidad que los trabajos anteriores habían dado al conflicto existencial, para concentrarse en una amplia reflexión sobre la forma" (Conde, 2008, p. 165). En definitiva es el propio Antonioni el que nos da la pista sobre la nueva forma de plantearse su obra cinematográfica: "Quiero contar historias diferentes con medios diferentes" (Godard, 1984, pp. 199-206), le decía a Jean-Luc Godard en 1964, también dos años antes de estrenarse Blow Up. Según Antonioni el contenido no puede estar ajeno a la forma que lo expresa.

Para cerrar esta idea sobre la concepción del arte reflejada por Antonioni, es necesario recordar la escena en su estudio en la cual Thomas, tras descubrir lo que realmente ha sucedido en el parque, se cruza con la hélice que está depositada en el suelo, entonces se detiene y la toca con el pie. Su gesto, en ese instante, denota algo que a los demás se nos escapa: él empieza a entender. Esta reacción de Thomas conecta gráficamente con este proceso interior que está viviendo y viene a confirmar la idea de que el arte no nos es suficiente para superar el drama de la vida, ese nuevo arte de los sesenta es un nuevo "entretenimiento", inútil ante lo implacable de la vida, el final, la muerte, la nada.

92 


\subsection{El acto fotográfico en Blow $U p$}

La representación y concepción del acto fotográfico en Antonioni corresponderá a la forma de concebir la imagen que estamos explicando: “[...] en el análisis de Blow Up, forma, color y focalización (o perspectiva), se incorporan a los textos de Antonioni estructurando una nueva temática, una reflexión metatextual sobre el propio valor del cine como re-creación o reflejo de lo real y, consecuentemente, sobre el valor de la imagen misma [...] defensa de la imagen como mecanismo que debe captar un significado que está más allá de lo real, un "algo" simbólico, válido sólo para una existencia y una estética entendidas, de manera radicalmente actual, como búsqueda inmanente y autorreferencial" (Conde, 2008, pp. 163-164).

Al igual que hiciera Donen, Antonioni utiliza el color de forma expresiva a partir de la reflexión artística: "Me interesa la dinámica del color; por eso me gusta tanto Pollock [recordamos que en Blow Up los cuadros pintados por Bill "emulan" a los de este artista estadounidense, referente del Expresionismo Abstracto y creador de la técnica denominada "Action painting”]. Sus cuadros tienen un ritmo extraordinario. Siempre he sentido la necesidad de utilizar el color de un modo funcional” (Fundación Luis Seoane, 2010, p. 14).

También, desde el punto de vista fotográfico o de la mirada, en Blow Up Antonioni provoca una ruptura del punto de vista. El de Thomas y el del espectador sólo coinciden en momentos determinados con lo cual provoca desorientación. Sin duda, lo que resalta de este tratamiento es que lo que le interesa al director italiano es el interior del individuo pero, en este caso, su personaje no enseña las razones que le mueven a hacer una cosa $u$ otra porque no interactúa con los demás, actitud que a la larga le llevará a no ser atendido cuando realmente pide ayuda tras conocer la existencia del asesinato del parque, único momento en el cual el espectador sí puede empatizar con sus inquietudes.

Sin embargo, en la escena del parque, clave para entender el acto fotográfico en la película de Antonioni, Thomas se comporta como un "cazador" de 
instantáneas. Santos Zunzunegui en su libro Pensar la imagen habla sobre el poder que otorga la cámara al fotógrafo que lo hace convertirse en "voyeur universal" porque el hecho de controlar las imágenes lo convierte en

poderoso. Su actitud posterior con la chica, la cual ha visto amenazada su intimidad - con la que tiene un forcejeo primero y un abierto enfrentamiento después- es de arrogancia y, al mismo tiempo, de indiferencia ante la angustia de ella, a él sólo le interesan sus fotografías “[...] Y ello porque la fotografía es el lugar de la radical indiferencia ante el mundo: la foto funciona a modo de invocación que no espera respuesta (Bonitzer, 1979) [...] En la foto se tiende a valorar la sangre fría que la ha hecho posible. Se abre así un foso insalvable entre el fotógrafo y lo fotografiado" (Zunzunegui, 2003, p. 135). Y esta actitud es la que derrocha el protagonista de Blow Up en casi toda la película: frialdad ante lo que ve y total ausencia de empatía.

\section{Conclusión}

La reunión de estos dos directores, "a simple vista", tan dispares, tanto estética como éticamente no deja de sorprendernos porque en ellos hay un nexo de unión esencial: su preocupación por transmitir a partir de la forma, del color, de la imagen, las relaciones humanas condicionadas, a su vez, por la dimensión temporal. Otra conexión sería su tendencia a "filmar" energías más que personajes concretos. Y mientras Stanley transmite en su cine la alegría de vivir, aunque matizada, encontramos en el de Antonioni la indiferencia analítica. Desde una aproximación diametralmente opuesta en cuanto al planteamiento moral y estético de sus respectivas obras, estos directores llegan a la misma sazón articulando una doble pregunta: cómo dar sentido a la vida y de qué modo encarar ese reto. De este modo, podríamos definir el cine de ambos creadores como arte del instante que en estas películas que ofrecemos se hace metáfora representada en una múltiple instantánea fotográfica.

A partir del acto fotográfico ambos elaboran un estudio de su realidad circundante y aunque pareciera que Donen no indaga tanto en el interior del 
individuo no es así. Sabemos, por lo que hemos investigado, que Antonioni tiene la preocupación palpable de definir el porqué de la incomprensión humana y el desarraigo del hombre contemporáneo ${ }^{2}$ pero Donen, aunque sometido a las normas rígidas de acción que le proporcionaba trabajar en unos grandes estudios bajo las órdenes de productores que exigían productos determinados, no por ello, renunció a reflexionar, si acaso, eso sí, estilísticamente, sobre el hombre de su tiempo y los diversos modos de vida posibles en nuestra época a través de las relaciones entre diferentes personas y ambientes. Por tanto, ambos directores a partir del análisis de las apariencias examinan las relaciones humanas y sus respectivas épocas. He aquí la virtud de estos dos filmes como documentos propiamente históricos y fuentes directas capaces de informar sobre la evolución sociocultural de sus respectivas épocas.

Como venimos diciendo, el tratamiento de las apariencias a partir de la forma y, esencialmente, del color es su principal punto de conexión. Donen lo hace de manera estilizada, aprovechando la tecnología proporcionada por Vistavision Technicolor -procedimiento consistente en la impresión de un negativo dos veces y media mayor que el normal y del cual se obtienen las copias positivas, por reducción al tamaño corriente, lo cual permite proyectarlas en las dimensiones que se quiera- mientras que Antonioni le otorga un sentido funcional.

No obstante, ambos directores llegan a la misma conclusión: la realidad se puede manifestar en múltiples facetas-apariencias y la forma de expresarlas puede conceder distintas visiones de la misma. El color, tiene la importancia de ser uno de los medios más subjetivos con el que cuenta cualquier creador y más si nos referimos al trabajo de los diseñadores de moda, elemento que ambos directores supieron valorar y trasladar a sus películas. Este elemento tiene mucho poder de atracción o rechazo dependiendo del uso que se le otorgue y forma parte fundamental de la base de un buen diseño y la clave de su éxito.

2 Recordemos, sin embargo, que en Blow Up esta constante en la obra del ferrarés queda en segundo plano porque en este filme le preocupa más la manera formal de transmitir esto que la propia idea de ello. 
La brillantez del color en Funny Face tiene que ver con la intensidad o nivel de energía que se quería conseguir. Los colores de su paleta son en Donen el objeto de su reto: encontrar esa expresividad cromática capaz de crear una dramaturgia del color. La luminosidad o brillo imperan en esta película. En ella los colores claros descubren los alrededores y sugieren liviandad, descanso, suavidad y fluidez y envían un mensaje de distensión. Son el color marfil, rosa, celeste, beige. Sus opuestos, aquellos que en principio usa Jo, encierran el espacio y lo hacen parecer más pequeño. Estos colores oscuros son concentrados y serios en su efecto. Por ejemplo, la escena del número musical "How long has this been on?", en la que Jo empieza a sentir que se ha enamorado de Avery, los colores de un sombrero, dejado durante una sesión de fotos hecha por el fotógrafo, anuncian el cambio en la vida interior de la joven. Así, el amarillo, que se opone al serio marrón oscuro del entorno, alude a la fantasía, el naranja a la expansión de la alegría y el verde a la frescura de lo que está empezando a sentir. Por tanto, combinar juntos los colores claros y los oscuros es una manera común y dramática de representar los opuestos de la naturaleza, tales como el día y la noche, algo que usa Donen para representar el antagonismo vital de los protagonistas que acaban fundiéndose en el blanco, en el no color, aquel que expresar paz, luz, felicidad, pureza, inocencia, amor.

Sin embargo, en la película de Antonioni hay una mayor saturación del color aludiendo así a la búsqueda por parte de este director de determinados sentimientos en el espectador. Él comprendió la carga emocional derivada del color a partir de la comprensión de la obra de pintores como Rotko, Ernst, Mondrian, Tanguy, Chagall, De Chirico. Como hemos visto anteriormente, la pintura fue para Antonioni origen de reflexión particular sobre la imagen. En su "Montañas Mágicas" decide fotografiar la pintura y ampliar esas instantáneas y en su película, como se dijo, lo hace desde la observación del detalle, de lo "abstracto", como una atomización de la imagen que de sentido al todo. El color será para él el instrumento capaz de evidenciar las motivaciones del hombre contemporáneo pero también le servirá para sugerir la necesidad de una regeneración conceptual y moral que 
debe ser también estética y formal. Por ejemplo, el color rojo, que el director italiano se preocupó en poner en determinados lugares de Londres por los que pasa Thomas con su descapotable, se proyecta hacia fuera y atrae la atención. Se trata de un color ardiente, fuerte y agresivo y parece vibrar dentro de su espacio propio. Éste afecta de muchas maneras, tales como el aumento de la presión sanguínea y la estimulación del sistema nervioso. Por otro lado, el protagonista lleva siempre el mismo atuendo, una camisa de color azul cielo que contrasta con la intensidad del rojo. Es un color frío que, en este caso, más que proporcionar sensación de calma nos sitúa en la propia actitud de Thomas ante lo que piensa o le sucede a lo largo de la película frialdad e indiferencia. Y para describir la vida del fotógrafo Antonioni utiliza esencialmente tres matices de colores: colores intensos y llamativos para las escenas más frívolas, los tonos verdes para los momentos de confusión y misterio y el blanco y negro tradicional para las escenas que muestran la cruda realidad. Este uso intencionado de colores relacionados con determinados escenarios se yuxtapone a lo largo de la historia de forma "desordenada", algo que evoca directamente a la pura realidad de la vida. Es así que, como en el caso de Funny Face, también en esta película podríamos hablar de una dramaturgia del color.

\section{Referencias bibliográficas}

Antonioni, Michelangelo (1968). Blow Up, Las amigas, El grito, La aventura. Madrid: Alianza Editorial.

Antonioni, Michelangelo (2002). Para mí, hacer una película es vivir. Barcelona: Paidós- Memoria del cine 9.

Apollinaire, Guillaume (1912). La pinture nouvelle (Meditaciones estéticas. Los Pintores Cubistas). París: Les Soirées de Paris.

Bachmann, Gideon (1975). Antonioni alter China: Art Versus Science. En: Film Quarterly, vol.4, $\mathrm{n}^{\mathrm{o}}$ 28. Berkeley, California. University of California Press, pp. 26-30.

Benavent, Vicente (2012). Una temporada de cine. En: Vogue.es España, no 287 20/02/2012. http://www.vogue.es/celebrities/oscar/articulos/el-cine-y-lamoda/16131. 
Biskind, Peter (2004). Moteros tranquilos, toros salvajes, Barcelona: Ed. Anagrama.

Calefato, Patricia (2003). Moda y cine, Valencia: Engloba.

Conde, Aurora (2008). La precisión de la nada (reflexiones sobre “Blow Up”). En: Cuadernos de filología italiana, $\mathrm{n}^{0}$ 15, Madrid: Universidad Complutense de Madrid, pp. 157-179.

Cortazar, Julio (1986). Las Armas Secretas, Cuento "Las babas del diablo", Buenos Aires: Editorial Sudamericana Planeta, $20^{\mathrm{a}}$ ed.

Danto, Arthur (1999). Después del fin del arte, Capítulo 5: "De la estética a la crítica del arte", Barcelona: Paidós.

Dubois, Philippe (1983). El acto fotográfico. De la representación a la recepción, Barcelona: Paidós.

Fundación Luis Seoane (2010). Michelangelo Antonioni y las montañas encantadas. La intuición del hielo, Madrid: MAIA ediciones.

Godard, Jean-Luc (1984). La Nuit, L`Eclipse, L’Aurore. Entrevista con M.Antonioni. En: Revista Cahiers du Cinêma, $\mathrm{n}^{\mathrm{o}}$ 160, noviembre de 1964, Paris: La politique des auteurs, pp.199-206.

Losilla, Carlos (2005). Blow Up (Michelangelo Antonioni). En: Dirigido por...: Revista de cine, $\mathrm{n}^{\mathrm{o}}$ 349. Barcelona: Editorial DIRIGIDO POR S.L., pp. 68-69.

Marías, Miguel (1974). Stanley Donen. En: Dirigido por...: Revista de cine, $\mathrm{n}^{\mathrm{O}}$ 18, noviembre-diciembre. Barcelona: Editorial DIRIGIDO POR S.L.

Melendo, Ana (2010). ¿Está dirigido el “Arte Nuevo" a una minoría especialmente dotada? El caso de Michelangelo Antonioni. En: Fotocinema, revista científica de Cine y fotografía, $\mathrm{n}^{\mathrm{O}}{ }_{1}$. Málaga: Universidad de Málaga, pp. 89-100.

Paredes, Israel (2006). (20) Miradas de Antonioni. En: Versión Original: Revista de cine, $\mathrm{n}^{\mathrm{O}}$ 136, Cáceres: Rebross, pp. 27-32.

Tejero, Juan (2010). Audrey Hepburn: una princesa en la corte de Hollywood, Madrid: TB Editores.

William, James S. (2008). The rhythms of life: an appreciation of Michelangelo Antonioni, extreme aesthete of the real. En: Film Quartely, Fifty Years 50 (1958-2008), vol.62, no 1. Berkeley, California: University of California Press, pp. 46-57.

Zunzunegui, Santos (1998). Pensar la imagen, Madrid: Cátedra. 